\title{
The hidden ecological resource of andic soils in mountain ecosystems: evidence from Italy
}

\author{
Fabio Terribile $^{1,2}$, Michela Iamarino ${ }^{1}$, Giuliano Langella ${ }^{1}$, Piero Manna ${ }^{2,3}$, Florindo Antonio Mileti ${ }^{1}$, \\ Simona Vingiani ${ }^{1,2}$, and Angelo Basile ${ }^{2,3}$ \\ ${ }^{1}$ Department of Agricultural Sciences, University of Naples Federico II, Via Università 100, 80055 Portici (Naples), Italy \\ ${ }^{2}$ CRISP, Interdepartmental Research Centre on the Earth Critical Zone, University of Naples Federico II, Via Università 100, \\ 80055 Portici (Naples), Italy \\ ${ }^{3}$ Institute for Mediterranean Agricultural and Forestry Systems, National Research Council of Italy, Via Patacca 85, \\ 80056 Ercolano (Naples), Italy
}

Correspondence: Fabio Terribile (terribilesci@gmail.com)

Received: 9 June 2017 - Discussion started: 9 August 2017

Revised: 1 November 2017 - Accepted: 20 November 2017 - Published: 31 January 2018

\begin{abstract}
Andic soils have unique morphological, physical, and chemical properties that induce both considerable soil fertility and great vulnerability to land degradation. Moreover, they are the most striking mineral soils in terms of large organic $\mathrm{C}$ storage and long $\mathrm{C}$ residence time. This is especially related to the presence of poorly crystalline clay minerals and metal-humus complexes. Recognition of andic soils is then very important.

Here we attempt to show, through a combined analysis of 35 sampling points chosen in accordance to specific physical and vegetation rules, that some andic soils have an utmost ecological importance.

More specifically, in Italian non-volcanic mountain ecosystems ( $>600 \mathrm{~m}$ a.s.1.) combining low slope $(<21 \%)$ and highly active green biomass (high NDVI values) and in agreement to recent findings, we found the widespread occurrence of andic soils having distinctive physical and hydrological properties including low bulk density and remarkably high water retention. Most importantly, we report a demonstration of the ability of these soils to affect ecosystem functions by analysing their influence on the timescale acceleration of photosynthesis estimated by NDVI measurements.

Our results are hoped to be a starting point for better understanding of the ecological importance of andic soils and also possibly to better consider pedological information in $\mathrm{C}$ balance calculations.
\end{abstract}

\section{Introduction}

Andic soils (i.e. soils with evident andosolization process) are known to have a unique set of morphological, physical, and chemical soil properties. Andosolization (Ugolini et al., 1988; Shoji et al., 1993) is a major soil-forming process regardless of whether these soils meet or do not meet the soil classification criteria for Andosol/Andisol. Among the peculiar soil properties of andic soils are (i) high porosity (bulk density generally $<0.90 \mathrm{~g} \mathrm{~cm}^{-3}$ ), (ii) friable consistency, (iii) high water retention capacity, (iv) large reserves of easily weatherable mineral and glass components, and (v) high susceptibility to liquefaction (Nanzyo, 2002; Iwata, 1968; Furuhata and Hayashi, 1980; Saigusa et al., 1987; Nanzyo et al., 1993). Moreover, Andosols are among the mineral soils having the largest $\mathrm{C}$ storage capacity (e.g. within $100 \mathrm{~cm}$ of depth the highest values found are on average $29.4 \mathrm{~kg} \mathrm{~m}^{-2}$ in Humic Andosols; Batjes, 1996) and long C residence time (Post, 1983; Batjes, 1996; Amundson, 2001). These peculiar properties can be ascribed to the presence of poorly crystalline clay minerals (Basile-Doelsch et al., 2005) and fungal and arthropodal soil organic matter (Nierop et al., 2005), but also to the specific physical and chemical properties that make these soils some of the world's most fertile (Leamy, 1984; Shoji et al., 1993; McDaniel et al., 2005). Despite these characteristics associated with $\mathrm{C}$ storage, andic properties are simply not considered in global carbon balance estimates (e.g. IPCC, 2006; Luo et al., 2016). In fact in these estimates - in the best cases - the contribution 
of soils (Parton et al., 1987) is limited to organic C and soil texture parameters, ignoring other important chemical and physical properties. Furthermore, the use of texture data for soils difficult to disperse, such as Oxisols and Andisols (Bartoli et al., 1991; Churchman et al., 1999; Bartoli and Burtin, 2007), introduces an analytical artefact in the global carbon balance.

This lack of acknowledgment of andic soils is becoming more important considering that in recent years andic soils have been found along with well-established volcanic landscapes (Shoji et al., 1993; Arnalds and Stahr, 2004; Lulli, 2007), in many non-volcanic mountain ecosystems (NVME) throughout the world (e.g. in Bhutan: Baumler et al., 2005; in Brazil: Dümig et al., 2008; in California: Graham and O'Geen, 2010; Rasmussen et al., 2010; in the Pacific Northwest, USA: McDaniel and Hipple, 2010; in Spain: Estevez et al., 2016; and also in Italy: Iamarino and Terribile, 2008; Scarciglia et al., 2008; Vingiani et al., 2014; Raab et al., 2017; Mileti et al., 2017).

The above lack of acknowledgment of the andic properties in carbon balance estimates is indeed unfortunate considering that (i) 2 or 3 times more $\mathrm{C}$ is stored in soils (Dixon et al., 1994) than occurs in the atmosphere as $\mathrm{CO}_{2}$, and most importantly (ii) that Andosols have such important $\mathrm{C}$ storage abilities (Torn et al., 1997) - being among the mineral soils having the largest $\mathrm{C}$ stock capabilities (Batjes, 1996).

Moreover, in view of their large $\mathrm{C}$ storage capability, the danger of degradation of andic soil is indeed high because they are some of the most vulnerable soils in the world in terms of soil erosion (Arnalds, 2001) and rapid-flow landslides (Basile et al., 2003; Terribile et al., 2007; Vingiani et al., 2015).

\subsection{Aim and rationale}

All the above shows the need for a much better understanding of the importance of andic soils and their ecological role. In this context, we focused on the Italian territory where andic soils in Italian NVME have been extensively addressed in terms of both their occurrence (Iamarino and Terribile, 2008) and genesis (Mileti et al., 2013). Thus, the aim of this contribution is to attempt to gain insight into the influence of andic soil in Italian NVME over (i) vegetation, through remotely sensed vegetation indices, and (ii) soil hydrological properties of utmost importance for plant growth.

To achieve the above, a combined approach has been undertaken, evaluating chemical and hydrological properties of 35 soils having different values of important parameters for identification of andic properties (such as $\mathrm{Al}_{\mathrm{o}}+0.5 \mathrm{Fe}_{\mathrm{o}}$ index and phosphate retention) in NVME (Fig. 1), as well as the NDVI dynamics of their sites.

All sites were chosen in order to select mountain soils (most of them are $>600 \mathrm{~m}$ a.s.1.) in conservative geomorphological settings (slope of the landscape $<21 \%$ ) and in areas with high primary productivity (estimated using time series max NDVI value) from different parts of Italy (see methods in Iamarino and Terribile, 2008).

The background to this approach is that (i) the above environmental factors can promote andosolization and (ii) most importantly, the great fertility of andic soils positively affects plant primary productivity in natural ecosystems. Hence the use of remotely sensed vegetation indices (i.e. NDVI, EVI, etc.) can be a valuable tool to address this topic. NDVI (Rouse at al., 1973) is strongly related to photosynthetic activity and has been widely used to estimate landscape patterns of primary production (Wang at al., 2004; Fensholt et al., 2012) and even net primary production (Tucker and Sellers, 1986). Moreover, time series of NDVI and the related NDVI metrics have proved to be a powerful tool for addressing plant dynamics and yield prediction in both agriculture and natural ecosystems at different scales (Reed et al., 1994; Zhang et al., 2003; Bolton and Friedl, 2013).

\section{Materials}

\subsection{Study area}

This specific work refers to the whole Italian mountain territory (Fig. 1). Italy lies between the 35 and $47^{\circ}$ north parallel and is located in the middle of the temperate zone of the Northern Hemisphere. It has an extremely complex territory. Two major mountain chains occupy more than $35 \%$ of the entire national surface: (i) the Apennines, with predominantly sedimentary rocks, spanning almost the entire Italian territory from $\mathrm{S}$ to N, with altitude reaching $2900 \mathrm{~m}$ a.s.1. (Gran Sasso), and (ii) the Alps, having predominantly metamorphic and igneous rocks, separating Italy from the rest of Europe, with maximum altitude over 4000 ma.s.l. (Monte Bianco, Monte Rosa, Monte Cervino). The remaining territory is mainly occupied by hilly systems (about 40\%) including those portions of the Apennines slowly degrading towards the sea, both at east and west. Plain systems only occupy just over $20 \%$ of the entire territory.

In general terms the climate - known to be mild (well known as Mediterranean) - is heavily influenced by the sea. With respect to Italian mountain areas it can be assumed that for soil climate (Soil Survey Staff, 2014) the mean moisture regime is udic (it may become ustic at lower elevation), whereas the mean temperature regime is generally mesic (it may become frigid and cryic at high elevation) (Costantini et al., 2004, 2013).

\subsection{Soil sampling}

Soil sampling was designed to collect fertile mountain soils in conservative geomorphological settings from different parts of Italy. The soils were sampled from (i) mountain environments (most soils were sampled $>600$ ma.s.l. estimated by a $270 \mathrm{~m}$ spatial resolution DEM obtained from the Italian Geological Service), (ii) geomorphological conservative 


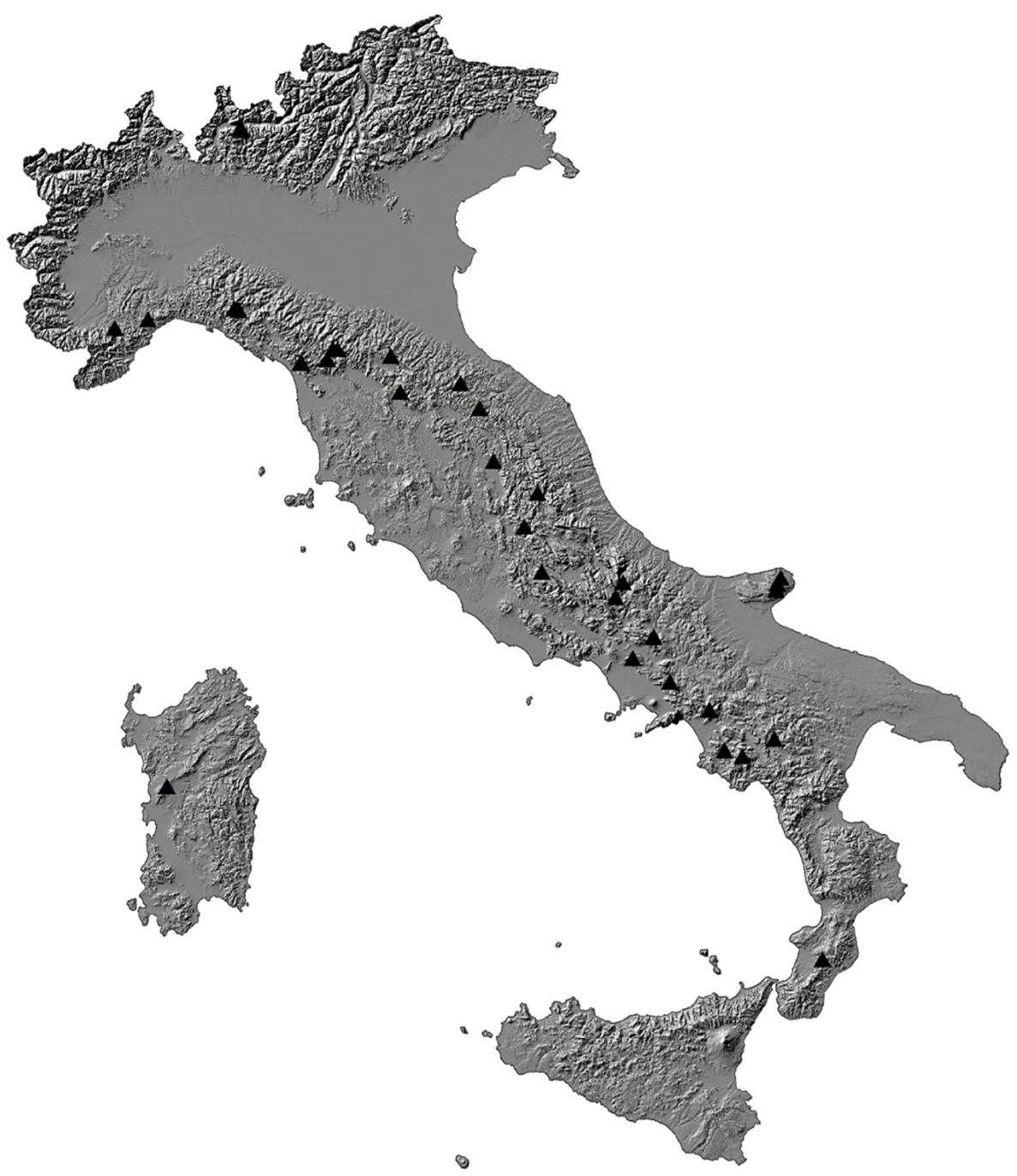

Figure 1. Location of the sampling points (black triangles).

landscapes with moderately low slopes (slope $<21 \%$ evaluated by the DEM) to minimize the risk of sampling eroded soils, and finally (iii) areas with high primary productivity estimated using the max NDVI value (NDVI threshold 0.65) obtained from MODIS Images MVC (https://modis.gsfc. nasa.gov/data/atbd/atbd_mod13.pdf) at $230 \mathrm{~m}$ spatial resolution for the period 28 July-13 August 2014 (which is a strong vegetative growth period in Italy). Morphological and chemical data (aggregated) of these pedons (28 soils after the selection reported in Sect. 2.3), along with the background to this methodology, are given in Iamarino and Terribile (2008). These information were further supplemented with data of seven additional soils: five newly surveyed and analysed soils, and two soils reported in the scientific literature and consistent with the previously stated rules. In detail, regarding the soils from the literature, one soil concerns research work in the Abruzzo region (Frezzotti and Narcisi, 1996) and one soil was retrieved from the ISRIC database (ISRIC, 2005).

\subsection{NDVI and land use data}

In-depth analysis on time-based NDVI was performed using a MODIS VI algorithm, which operates on a per-pixel basis and relies on multiple observations over a 16-day period to generate a maximum composite vegetation index (VI) based on the maximum value compositing (MVC) technique. In order to extract the NDVI metrics (maximum NDVI, integrated NDVI sum over the growing period, acceleration of photosynthesis or rate of green-up, NDVI derivatives) some pre-processing of the data were necessary (i.e. cloud contamination) following established procedures (Reed et al., 1994). After such processing, about $15 \%$ of the NDVI observations had to be discarded and the corresponding data set was excluded from this work. This is related to well-known problems in remote sensing, due to high and persistent cloud con- 
tamination and in some cases also to the presence of rock outcrops inside the area of the investigated pixels.

NDVI data were chosen to incorporate years having marked contrasting climate (wet/dry) and then, potentially contrasting vegetation indices trends and metric. After performing an analysis of the climatic database published by the Italian Ministry of Environment for the whole country (http://www.isprambiente.gov.it/), we chose the very dry year 2003, the very wet year 2014, and the 2005 year having an intermediate rainfall. More specifically, these years have the following climatic trends (values below are ranked in the order 2003, 2005, 2014 respectively):

- similar yearly mean temperature: $13,12,13^{\circ} \mathrm{C}$;

- evident differences in yearly mean maximum temperature: $36,35,33^{\circ} \mathrm{C}$;

- most importantly, marked differences in yearly cumulated rainfall $766 \mathrm{~mm}$ (SD: $172 \mathrm{~mm}$ ), $870 \mathrm{~mm}$ (SD: $231 \mathrm{~mm}$ ), $1143 \mathrm{~mm}$ (SD: $540 \mathrm{~mm}$ );

- marked differences in standardized precipitation index (McKee et al., 1993), varying in the range $-0.5-0.5$; $0.5-0.0 ; 1.0-2.0$. This index is a well-known simplified indicator for monitoring drought and periods of anomalously wet events and it shows droughts for year 2003 but also for 2005 .

The CORINE Land Cover (CLC hierarchical levels 4, 5) classification (EEA, 2007, and subsequent update EEA, 2012) was used to produce a preliminary evaluation of the main land covers. CLC classes were locally validated for each of the sampled sites. The reported land cover classes of chestnut, beech, and broadleaf oak must be considered classes of land cover where these species are dominant ( $>$ $80 \%$ ) but not exclusive. The grassland class refers to natural grassland having both continuous (tree and shrubs $<15 \%$ ) and discontinuous (tree and shrubs $15-40 \%$ ) pattern.

\section{Methods}

All the statistical analysis was performed using two-tailed tests; ANOVA (Tamhane method by Yosef and Tamhane, 2008) was performed for multiple comparisons of means. The reported test of significance for the latitude was performed on a "metres from the equator" basis.

At each site a soil profile was dug, described, and sampled (FAO, 2006). Bulk samples were collected (trowel) from all the soil horizons (126 horizons) for chemical analyses. Steel cylinders of about $200 \mathrm{~cm}^{3}$ were carefully inserted in the selected $\mathrm{A}$ and $\mathrm{B}$ horizons by an impact-absorbing hammer in order to collect undisturbed soil samples for hydrological analysis. The samples were collected on representative pedons (see Table S2 in the Supplement) of the three encountered soil types (Andosols, Cambisols, Phaeozems).
Bulk samples after air drying $\left(25^{\circ} \mathrm{C}\right)$ for 2 weeks were sieved to less than $2 \mathrm{~mm}$ and used for further analyses (USDA-NRCS, 2004): organic matter was determined following the Walkley-Black procedure (Walkley, 1947); $\mathrm{Al} / \mathrm{Fe} / \mathrm{Si}$ in the poorly crystalline oxides/hydroxides and in the organic matter were extracted with ammonium oxalate $\left(\mathrm{Fe}_{\mathrm{o}}, \mathrm{Al}_{\mathrm{o}}, \mathrm{Si}_{\mathrm{o}}\right.$,) treatment at $\mathrm{pH}=3$ (Schwertmann, 1964; Blakemore et al., 1987) and their contents were determined by inductively coupled plasma atomic emission spectroscopy (ICP-AES) Varian Liberty model 150. Values of Al and Fe extracted with ammonium oxalate were used to calculate the $\mathrm{Al}_{\mathrm{o}}+0.5 \mathrm{Fe}_{\mathrm{o}}$ index. This index is the key parameter for the assessment of andic soil properties (IUSS Working Group WRB, 2015; SSS, 2014). Then we use it to evaluate the andosolization process. The $\mathrm{Al}_{\mathrm{o}}+0.5 \mathrm{Fe}_{\mathrm{o}}$ index can be considered weak in the range $0.4-1.0 \%$, moderate in the range $1.0-$ $2.0 \%$ and well expressed over $2.0 \%$. The value of $0.4 \%$ of $\mathrm{Al}_{\mathrm{o}}+0.5 \mathrm{Fe}_{\mathrm{o}}$ index is the "key out" requirement for entering in the Andosols both in WRB (IUSS Working Group WRB, 2015) and USDA Soil Taxonomy (SSS, 2014) classifications. Phosphate retention was determined according to Blakemore et al. (1987).

In order to simplify the comparison between soil features and land use or NDVI metrics it was necessary to aggregate chemical data obtaining a single representative value for the whole soil. Therefore, the contents of $\mathrm{Al}_{\mathrm{o}}+0.5 \mathrm{Fe}_{\mathrm{o}}$, P retention, and organic carbon were weighted according to horizon thickness for each of the pedons. Soils were classified using the WRB system (IUSS Working Group WRB, 2015).

With respect to the hydrological analysis, 10 experimental points of the soil water retention curve $\theta(h)$, ranging from saturation to $-30 \mathrm{kPa}$ of potential, were determined through the use of a tension table and five points at $-100,-500$, $-800,-1200$, and $-1500 \mathrm{kPa}$ were determined through use of a pressure plate apparatus (Dane and Hopmans, 2002). The soil samples were then dismantled and dried for $24 \mathrm{~h}$ in the oven at $105^{\circ} \mathrm{C}$ in order to determine the water content from the weight data set and the bulk density.

The water retention experimental data were parameterized according to the unimodal $\theta(h)$ relationship proposed by van Genuchten (1980), expressed here in terms of the scaled water content:

$S_{\mathrm{e}}=\left[1+(\alpha|h|)^{n}\right]^{1-1 / n}$,

with $S_{\mathrm{e}}=\left(\theta-\theta_{\mathrm{r}}\right) /\left(\theta_{0}-\theta_{\mathrm{r}}\right)$, and in which $\alpha\left(\mathrm{cm}^{-1}\right)$ and $n$ are curve shape parameters. $\theta_{0}$ and $\theta_{\mathrm{r}}$ respectively represent the saturated water content (at $h=0$ ) and the residual water content, and may either be fixed or treated as parameters to be optimized.

To obtain a synthetic description of water retention for an easy comparison with soil chemical analysis, we used a numeric index (IRI) integrating the whole water retention function (Basile et al., 2007). 
The integral retention index, IRI, is defined by

$$
\mathrm{IRI}=\frac{1}{\mathrm{wp}} \int_{0.1}^{\mathrm{wp}} \theta \mathrm{d}\left(\log _{10}|h|\right),
$$

where $w p=4.2$ is the wilting point. This adimensional index $(0<$ IRI $<1)$ represents the average value of the function $\theta\left(\log _{10}|h|\right)$ on the interval [0,wp] and allows simple comparisons of the whole water retention by coalescing it in a single characteristic value.

\section{Results and discussion}

\subsection{Soil and landscape}

The outcome results of our procedure in terms of soil analysis and soil classification (IUSS Working Group WRB, 2015) show that Andosols and Cambisols alone account for more than $80 \%$ of the observations. Most interestingly, despite differences in soil classification, in the vast majority of cases (about two-thirds) there is a moderate and well-expressed andosolization process as estimated by $\mathrm{Al}_{\mathrm{o}}+0.5 \mathrm{Fe}_{\mathrm{o}}$ index (Fig. 2). Iamarino and Terribile (2008) have reported further data as horizon-based means on these pedons proving the general absence of podsolization and depicting a scenario where andosolization is the main soil process.

Table 1 reports the main geographical and land cover features of the studied soils along with NDVI metrics over three contrasting climatic years. As the data show (Table 1), Andosols, Cambisols, and Phaeozems occur at similar latitudes and elevations and beech, oak, chestnut, and grassland are the main land use. More specifically, the main land cover unit associated with Andosols and Cambisols is the beech forest, but they also occur with less frequency in other land uses (grassland, chestnut, and oak), whereas Phaeozems are mostly associated with grassland.

In all years, in sites where Andosols occur, the mean value of max NDVI, integrated sum of NDVI, and NDVI greenup is always the highest compared to other soil classes. This finding is very interesting and consistent with the high fertility of these soils. NDVI max and NDVI integrated sum (June-August) show significant differences between the different land cover classes, following clear diversity in plant biology.

The analysis of NDVI trend among the 3 investigated years shows that, as expected, NDVI max and NDVI sum values in the wetter 2014 (cumulated rainfall: $1143 \mathrm{~mm}$ ) are always higher than in the drier 2003 and 2005 (cumulated rainfall 766 and $870 \mathrm{~mm}$, respectively). Differently, the NDVI greenup values are typically higher in 2003-2005 as compared to 2014 and this NDVI green-up difference is even more pronounced moving towards the most andic soils (Andosols). All the above clearly suggest that andic soils - typically having higher water storage as compared to other soils - enabled

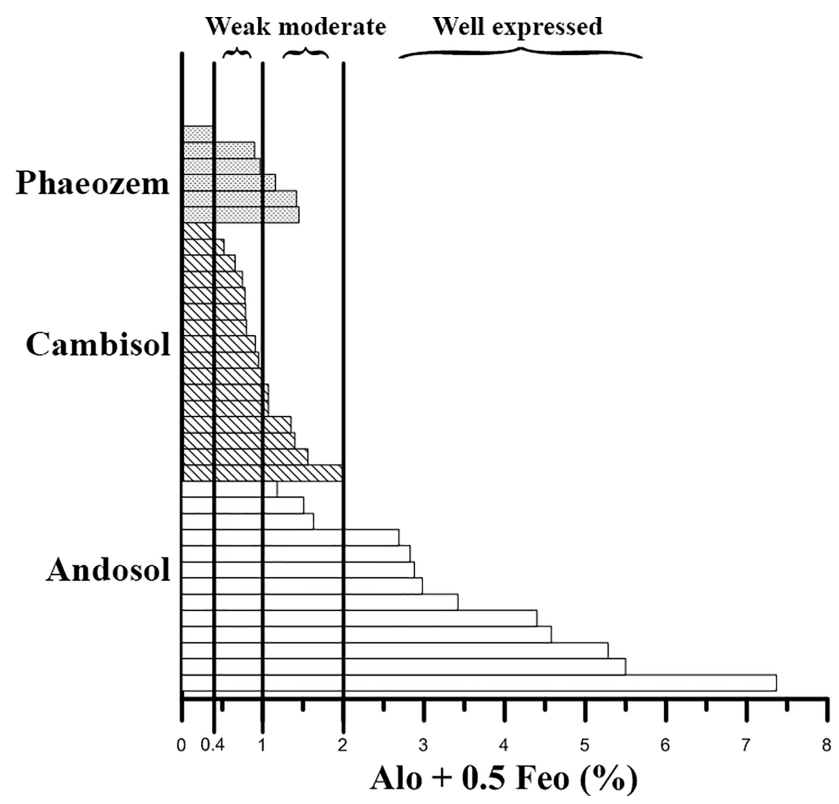

Figure 2. Soil type (IUSS Working Group, WRB, 2015) plotted against $\mathrm{Al}_{\mathrm{O}}+0.5 \mathrm{Fe}_{\mathrm{o}} \%$ (weighted mean according to horizon thickness for each of the studied pedons). The value of $0.4 \%$ in $\mathrm{Al}_{\mathrm{o}}+0.5 \mathrm{Fe}_{\mathrm{o}}$ is the "key out" requirement for entering in the Andosol (and/or Andisol) classes both in WRB (IUSS Working Group WRB, 2015) and USDA Soil Taxonomy (SSS, 2014) classifications. The $\mathrm{Al}_{\mathrm{O}}+0.5 \mathrm{Fe}_{\mathrm{o}}$ index can be considered weak in the range 0.4 1.0 , moderate in the range 1.0-2.0, and well expressed over 2.0 .

the production of a higher green-up. Here we must also add that further analysis would be required to evaluate at each site trends in soil water storage and temperature before the green-up phase.

Table 2 reports the main features of the studied soils. The soil data show that all soils are deep, and have a friable granular/crumb soil structure at the surface. Moreover, organic $\mathrm{C}$, the $\mathrm{Al}_{\mathrm{o}}+0.5 \mathrm{Fe}_{\mathrm{o}}$ index (always higher than $0.4 \%$, thus compatible with vitric/silandic/aluandic), and $\mathrm{P}$ retention range from moderate to high (mean org. C: $3.8 \%$; mean $\mathrm{Al}_{\mathrm{o}}+0.5 \mathrm{Fe}_{\mathrm{o}} \%: 2.0 \%$; mean $\mathrm{P}$ ret: $63 \%$ ). Of all the soils, Andosols have the highest (i) soil depth, (ii) $\mathrm{Al}_{\mathrm{o}}+0.5 \mathrm{Fe}_{\mathrm{o}} \%$ (weighted mean), and (iii) $\mathrm{P}$ retention \% (weighted mean). Phaeozems have the highest organic $\mathrm{C}$ (weighted mean) content.

Although $\mathrm{Al}_{\mathrm{o}}+0.5 \mathrm{Fe}_{\mathrm{o}}$ and $\mathrm{P}$ retention values in Andosols differ significantly, there are no such important differences between the various land cover classes, suggesting that in our case study vegetation is of little importance in determining the andosolization process - but of course this finding cannot be extrapolated to other settings. In fact there are many cases where vegetation type has a very close connection with soil type or soil properties (e.g. Ciarkowska and Miechowka, 2017).

In general terms, the investigated soils can be considered rather homogeneous in their morphological, chemical, and 
Table 1. Main geographical, land cover, soil and NDVI features of the studied soils.

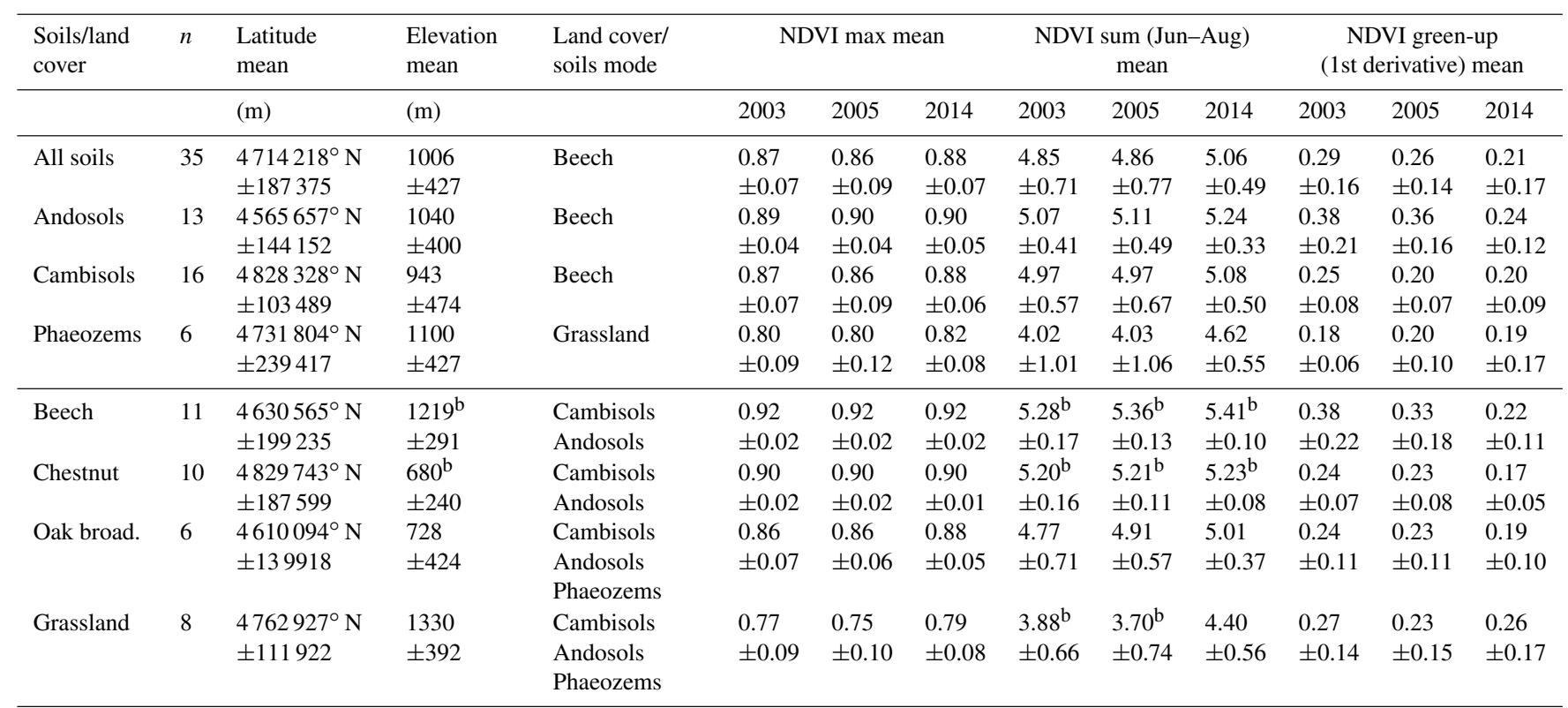

${ }^{\mathrm{a}} \alpha<0.05,{ }^{\mathrm{b}} \alpha<0.01$ (two-tailed test). $n$, number of observations; broad., broadleaf species. The symbol \pm after the mean value shows the SD. The ( $n$ ) values refer to the number of observation available for NDVI analysis (see methods); in some sites because of strong cloud contamination not all the data could be used for NDVI analysis. The upper part of the table refers to soil types (IUSS Working Group WRB, 2015) and the lower part refers to land cover (CORINE Land Cover classes by APAT, 2000) after site validation. NDVI MODIS metrics refer to a whole 2003, 2005, 2014 time series (16-day step).

Table 2. Main features of the studied soils.

\begin{tabular}{lcclcccc}
\hline $\begin{array}{l}\text { Soils/land } \\
\text { cover }\end{array}$ & $n$ & $\begin{array}{c}\text { Soil depth } \\
\text { solum }) \text { mean } \\
(\mathrm{cm})\end{array}$ & $\begin{array}{l}\text { Structure of surface A } \\
\text { horizon mode }\end{array}$ & & $\begin{array}{c}\text { Organic C } \\
\text { mean } \\
\% o\end{array}$ & $\begin{array}{c}\mathrm{Al}_{\mathrm{o}}+0.5 \mathrm{Fe}_{\mathrm{o}} \\
\text { mean } \\
\%\end{array}$ & $\begin{array}{c}\mathrm{P} \mathrm{retention} \\
\text { mean } \\
\%\end{array}$ \\
\hline All soils & 35 & $88 \pm 37$ & Friable Gr. Cr. medium & 37 & $38.0 \pm 23.0$ & $2.0 \pm 1.7$ & $62.9 \pm 26.0$ \\
Andosols & 13 & $115^{\mathrm{b}} \pm 34$ & Friable Gr. Cr. medium & 69 & $45.3 \pm 26.6$ & $3.6^{\mathrm{b}} \pm 1.8$ & $90.2^{\mathrm{b}} \pm 14.6$ \\
Cambisols & 16 & $75 \pm 31$ & Friable Gr. Cr. fine; Cr. coarse & 21 & $27.3 \pm 15.1$ & $1.0 \pm 0.4$ & $46.9 \pm 17.2$ \\
Phaeozems & 6 & $66^{\mathrm{b}} \pm 21$ & Friable Gr. Cr. medium & 57 & $50.9 \pm 22.8$ & $1.0 \pm 0.4$ & $49.1 \pm 16.5$ \\
Beech & 11 & $102 \pm 28$ & Friable Gr. Cr. medium & 41 & $40.6 \pm 22.9$ & $2.6 \pm 1.7$ & $83.6 \pm 21.6$ \\
Castanea & 10 & $95 \pm 38$ & Friable Gr. Cr. coarse & 40 & $23.5 \pm 10.8$ & $1.8 \pm 2.1$ & $42.7 \pm 21.9$ \\
Oak broad. & 6 & $70 \pm 55$ & Friable Gr. Cr. Fine & 25 & $34.2 \pm 22.3$ & $1.8 \pm 1.8$ & $61.3 \pm 27.5$ \\
Grassland & 8 & $75 \pm 25$ & Friable Gr. Cr. medium & 50 & $55.6 \pm 25.4$ & $1.5 \pm 0.7$ & $57.5 \pm 16.7$ \\
\hline
\end{tabular}

${ }^{\mathrm{a}} \alpha<0.05,{ }^{\mathrm{b}} \alpha<0.01$, (two-tailed test). $n$, number of observations; broad., broadleaf species; Gr., granular; Cr., crumb; fine: $<2 \mathrm{~mm}$; medium: $2-5 \mathrm{~mm}$; coarse: $5-10 \mathrm{~mm}$; very coarse: $>10 \mathrm{~mm}$. The symbol \pm after the mean value shows the SD. The upper part of the table refers to soil types (IUSS Working Group WRB, 2015) and the lower part refers to land cover (CORINE Land Cover classes, by APAT, 2000) after site validation. Chemical analyses are integrated over soil depth (solum).

physical properties, although they occur in very diverse geological and climatic mountain ecosystems; a preliminary cautious estimate (Iamarino, 2005) of their distribution in Italy has shown their presence on about $7 \times 10^{5}$ ha.

This finding parallels similar ones in other parts of the world where mountain andic soils (not necessarily Andosols) have been reported in Bhutan (Baumler et al., 2005), in Brazil (Dümig et al., 2008), in California (Graham and O'Geen, 2010; Rasmussen et al., 2010), the Pacific Northwest, USA (McDaniel and Hipple, 2010), NW Spain (Estevez et al.,
2016), and also in Italy (Iamarino and Terribile, 2008; Scarciglia et al., 2008; Vingiani et al., 2014).

\subsection{Andosolization process and soil hydrology}

Given the finding on the importance of andic soils (albeit not Andosols) in Italian non-volcanic uplands, the question is raised as to whether the andosolization process is also connected to those physical properties considered of key importance for plant growth, namely bulk density and water retention due to their crucial role in water availability. In order to address this issue, a selection of horizons $\mathrm{A}$ and $\mathrm{B}$ of the 
Table 3. Main physical parameters of selected soil horizons.

\begin{tabular}{lcccccccc}
\hline & \multicolumn{2}{c}{$\begin{array}{l}\text { Mean bulk } \\
\text { density }\end{array}$} & \multicolumn{2}{c}{$\begin{array}{c}\text { Mean WC } \\
\text { at } \mathrm{pF}=4.2\end{array}$} & $\begin{array}{l}\text { Mean WC } \\
\text { at } \mathrm{pF}=0\end{array}$ & \multicolumn{2}{c}{ IRI } \\
\hline Horizons & $n$ & $\mathrm{~g} \mathrm{~cm}^{-3}$ & $n$ & $\mathrm{~cm}^{3} \mathrm{~cm}^{-3}$ & $n$ & $\mathrm{~cm}^{3} \mathrm{~cm}^{-3}$ & $n$ & \\
\hline All & 35 & $0.87 \pm 0.21$ & 83 & $0.25 \pm 0.09$ & 16 & $0.79 \pm 0.10$ & 16 & $0.51 \pm 0.06$ \\
A & 16 & $0.79 \pm 0.17$ & 55 & $0.27 \pm 0.09$ & 07 & $0.85 \pm 0.07$ & 07 & $0.55 \pm 0.04$ \\
B & 19 & $0.93 \pm 0.22$ & 27 & $0.19 \pm 0.07$ & 10 & $0.75 \pm 0.10$ & 10 & $0.48 \pm 0.06$
\end{tabular}

$n$ : number of observations; WC: volumetric water content; IRI: integrated water retention index. The symbol \pm after the mean value shows the SD. The table reports for soil horizons $\mathrm{A}$ and $\mathrm{B}$ mean bulk density, water retention at two different values of $\mathrm{pF}(0$ and 4.2$)$ corresponding to the pressure head of -0.1 and $-1500 \mathrm{kPa}$, respectively, and the integrated retention index (IRI) which coalesces the water retention curve in a single value (Basile et al., 2007).

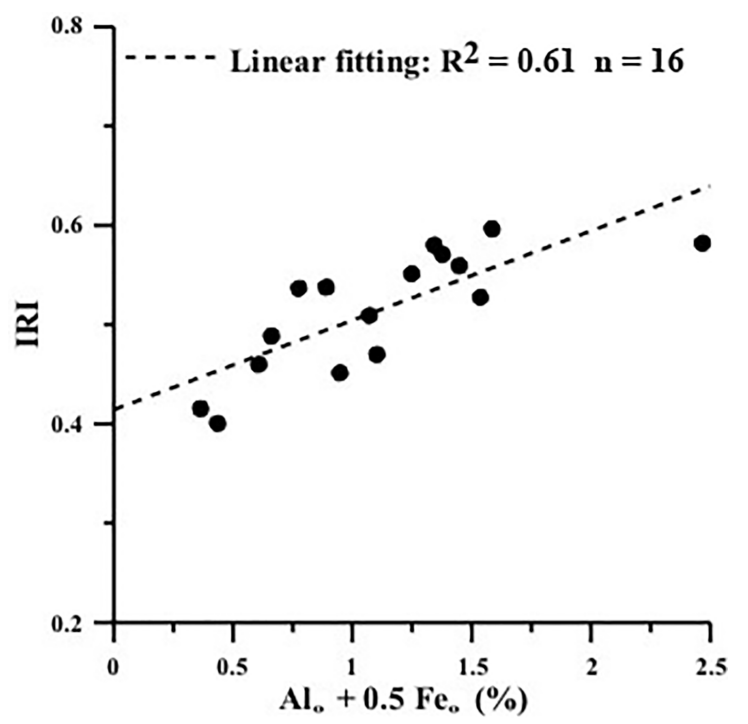

Figure 3. Scatterplot between $\mathrm{Al}_{\mathrm{O}}+0.5 \mathrm{Fe}_{\mathrm{o}}$ index and integrated retention index (IRI) determined in reference $\mathrm{A}$ and $\mathrm{B}$ horizons. Coefficient of determination $R^{2}$ along with points $(n)$ is reported.

previously investigated soils was analysed. The data (in Table 3) clearly show the occurrence of very porous soils (low bulk density) and very high water retention capability over the complete range of pressure head values. Surface A horizons generally have lower bulk density and higher water retention (as shown in Table 3) than the subsoil B horizons, which must be ascribed to the contribution of organic carbon in improving the soil structure (Kutilek and Nielsen, 1994) and therefore increasing water retention and decreasing bulk density.

The positive high correlation (Fig. 3) between $\mathrm{Al}_{\mathrm{o}}+0.5 \mathrm{Fe}_{\mathrm{o}}$ index and IRI - determined in selected A and B horizons - indicates that the more advanced the andosolization process, the higher the integrated water retention, and hence very good soil physical properties. This result is already established (Basile et al., 2007) but only for soils having $\mathrm{Al}_{\mathrm{o}}+0.5 \mathrm{Fe}_{\mathrm{o}}$ larger than $2 \%$, while there is no positive evidence for soils having much lower $\mathrm{Al}_{\mathrm{o}}+0.5 \mathrm{Fe}_{\mathrm{o}}$ index val- ues (e.g. in the range 0.4-2.0\%). All the above emphasizes that poorly ordered clay minerals greatly affect soil physical properties even at moderate to low content, which in turn could greatly affect water storage and then water availability for plant ecosystem growth.

Such finding is important because it does not refer to soils in a unique location but rather to a large variety of soils developed at different latitudes and over different bedrocks and land uses.

\subsection{Andosolization process and elevation against NDVI metrics}

To investigate this question further, bivariate correlation (Table 4) and regression analyses (Fig. 4) were performed between $\mathrm{Al}_{\mathrm{o}}+0.5 \mathrm{Fe}_{\mathrm{o}}$ index and NDVI metrics for each of the observed land cover classes. In the vast majority of climatic years and land cover classes, the $\mathrm{Al}_{\mathrm{o}}+0.5 \mathrm{Fe}_{\mathrm{o}}$ index has a positive correlation with NDVI metrics but, generally, not significant for (i) NDVI max value and (ii) integrated sum of NDVI (Table 4). By contrast, rather astonishingly, the $\mathrm{Al}_{\mathrm{o}}+0.5 \mathrm{Fe}_{\mathrm{o}}$ index is always well correlated with the rate of green-up (first derivative of NDVI); this correlation is significant for the driest years 2003 and 2005 and not for the wettest 2014. Highest significant correlations are found when each land use is considered separately. For instance, in 2003 the Pearson's correlation coefficient $r$ between $\mathrm{Al}_{\mathrm{o}}+0.5 \mathrm{Fe}_{\mathrm{o}}$ index and green-up is 0.82 for beech and 0.83 for grassland, while in the year 2005 it is 0.86 for beech and 0.90 for grassland. These results show that beech and grassland are the land use types where the ecological importance of the andosolization process is more evident; furthermore, the data producing this high correlation span a high range of $\mathrm{Al}_{\mathrm{O}}+0.5 \mathrm{Fe}_{\mathrm{o}}$ index values (see Fig. 4). This performance could be explained considering that (i) beech and grassland are more spatially homogeneous land uses as compared to oak broadleaves (e.g. oak land use is more heterogeneous, being a potential mixture of very different species, sometimes even including grassland), (ii) beech and grassland land uses are less affected by strong land management practices as compared to chestnut (which in the Italian landscape is often 

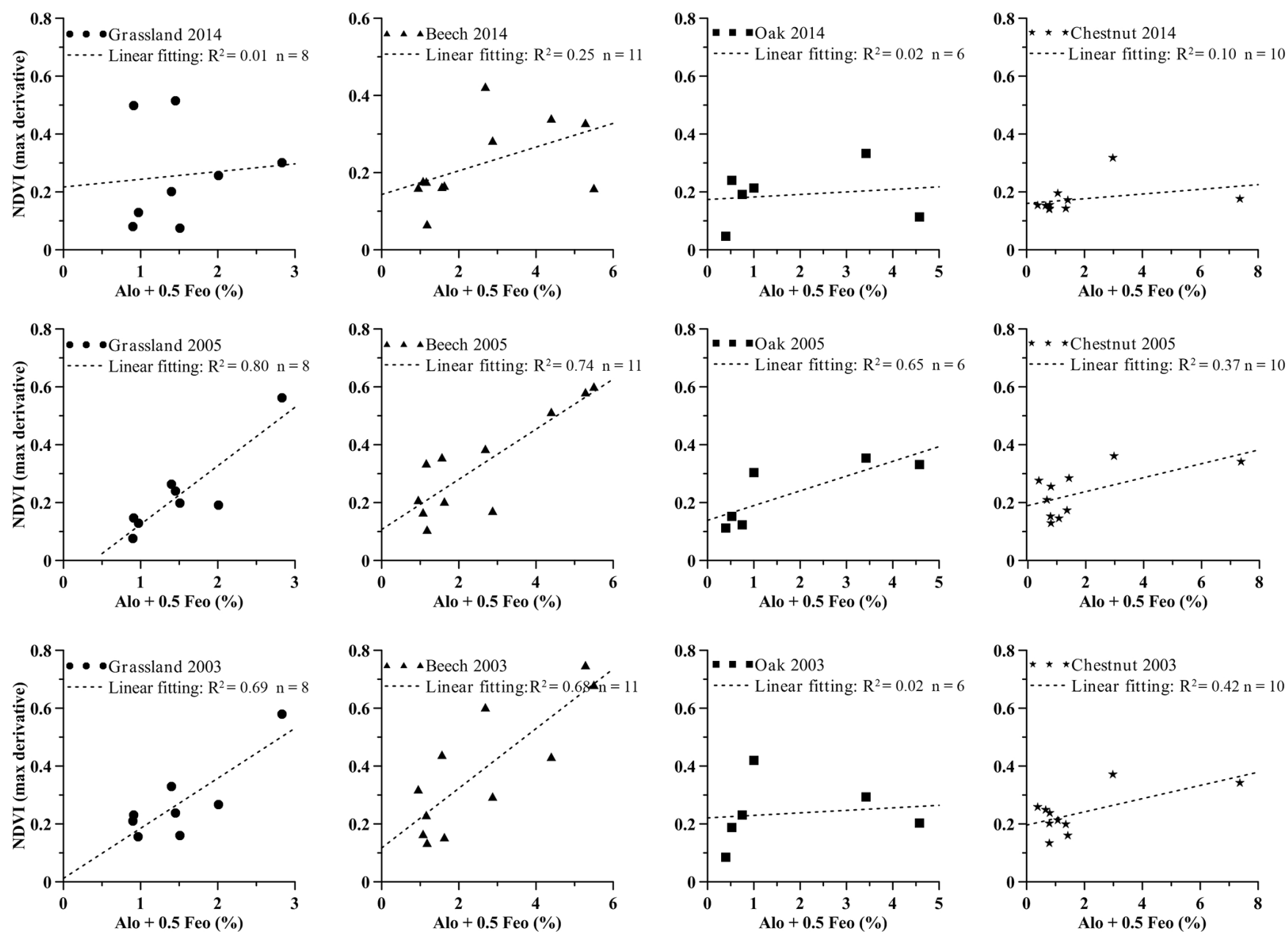

Figure 4. Scatterplot between $\mathrm{Al}_{\mathrm{O}}+0.5 \mathrm{Fe}_{\mathrm{o}}$ index (weighted mean $\mathrm{Al}_{\mathrm{O}}+0.5 \mathrm{Fe}_{\mathrm{o}} \%$ according to horizon thickness for each of the studied pedons) and the maximum value of the NDVI derivative. From left to right: grassland, beech, oak, and chestnut. From bottom to top: year 2003, 2005, and 2014. The dashed lines show the linear regression for each land cover. Coefficient of determination $R^{2}$ along with data points $(n)$ is reported for each panel.

managed as coppice), and (iii) moreover, it is well known that beech is very susceptible to severe water stress (Teissier et al., 1981).

All the above can well explain the more responsive NDVI signal of beech and grassland to water stress as compared to oak broadleaves and chestnut.

This is the first time that a close connection between NDVI metrics and the andosolization process has been shown. This result can have important consequences in terms of better understanding the ecology of Italian mountain ecosystems.

Differently, in many different environments often a positive variation of NDVI against elevation has been reported (Zhan et al., 2012; Walsh et al., 2001; Chen et al., 2006). Thus, since the andosolization process has been assessed in mountain areas, it was important to test whether the observed relationship between NDVI metrics and the $\mathrm{Al}_{\mathrm{o}}+0.5 \mathrm{Fe}_{\mathrm{o}}$ index disguises a possibly even closer relationship between NDVI metrics and elevation.
In relation to this, Table 4 shows that the correlation between NDVI metrics and elevation is confused, with much lower $r$ values as compared with that between NDVI and the $\mathrm{Al}_{\mathrm{o}}+0.5 \mathrm{Fe}_{\mathrm{o}}$ index. Overall, both the low and negative $r$ values between many NDVI metrics and elevation show that altitude (and possibly its covariates, i.e. temperature and rainfall) do not adequately explain variations in green active biomass parameters. Moreover, $r$ values between $\mathrm{Al}_{\mathrm{o}}+0.5 \mathrm{Fe}_{\mathrm{o}}$ index and elevation show very low values (e.g. $r=0.16$ for all sites) and do not show any consistent trend (data not shown).

Thus we can state that, for the first time, here the ecological importance of the andosolization process over different land use canopies in a large part of the Italian mountains has been demonstrated. Most probably this finding is connected to the unique hydropedological properties of these soils. In fact, this result is especially evident in the driest years (2003, 2005), while it is less important in the wettest year (2014), 
Table 4. Bivariate correlation analysis.

\begin{tabular}{|c|c|c|c|c|c|c|c|c|c|}
\hline & \multicolumn{9}{|c|}{$\mathrm{Al}_{\mathrm{O}}+0.5 \mathrm{Fe}_{\mathrm{o}}(\%)$} \\
\hline & \multicolumn{3}{|c|}{2003} & \multicolumn{3}{|c|}{2005} & \multicolumn{3}{|c|}{2014} \\
\hline & $\begin{array}{r}\text { Mean } \\
\text { NDVI } \\
\max \end{array}$ & $\begin{array}{r}\text { Mean } \\
\text { NDVI sum } \\
\text { (Jun-Aug) }\end{array}$ & $\begin{array}{r}\text { Mean NDVI } \\
\text { green-up (1st } \\
\text { derivative) }\end{array}$ & $\begin{array}{r}\text { Mean } \\
\text { NDVI } \\
\max \end{array}$ & $\begin{array}{r}\text { Mean } \\
\text { NDVI sum } \\
\text { (Jun-Aug) }\end{array}$ & $\begin{array}{r}\text { Mean NDVI } \\
\text { green-up (1st } \\
\text { derivative) }\end{array}$ & $\begin{array}{r}\text { Mean } \\
\text { NDVI } \\
\max \end{array}$ & $\begin{array}{r}\text { Mean } \\
\text { NDVI sum } \\
\text { (Jun-Aug) }\end{array}$ & $\begin{array}{r}\text { Mean NDVI } \\
\text { green-up (1st } \\
\text { derivative) }\end{array}$ \\
\hline All sites ( $n: 35)$ & 0.19 & 0.19 & $0.61^{\mathrm{b}}$ & 0.17 & 0.20 & $0.71^{\mathrm{b}}$ & 0.16 & 0.20 & 0.23 \\
\hline Beech & 0.36 & -0.09 & $0.82^{\mathrm{b}}$ & 0.24 & 0.20 & $0.86^{\mathrm{b}}$ & 0.42 & $0.60^{\mathrm{a}}$ & 0.50 \\
\hline Oak & 0.16 & 0.28 & 0.14 & 0.12 & 0.29 & 0.81 & 0.20 & 0.28 & 0.15 \\
\hline Chestnut & -0.01 & -0.21 & $0.65^{\mathrm{a}}$ & -0.13 & -0.004 & 0.61 & -0.21 & -0.01 & 0.32 \\
\hline \multirow[t]{4}{*}{ Grassland } & -0.46 & 0.26 & $0.83^{\mathrm{a}}$ & -0.01 & 0.02 & $0.90^{\mathrm{b}}$ & -0.35 & -0.31 & 0.10 \\
\hline & \multicolumn{9}{|c|}{ Elevation } \\
\hline & \multicolumn{3}{|c|}{2003} & \multicolumn{3}{|c|}{2005} & \multicolumn{3}{|c|}{2014} \\
\hline & $\begin{array}{r}\text { Mean } \\
\text { NDVI } \\
\max \end{array}$ & $\begin{array}{r}\text { Mean } \\
\text { NDVI sum } \\
\text { (Jun-Aug) } \\
\end{array}$ & $\begin{array}{r}\text { Mean NDVI } \\
\text { green-up (1st } \\
\text { derivative) }\end{array}$ & $\begin{array}{r}\text { Mean } \\
\text { NDVI } \\
\max \end{array}$ & $\begin{array}{r}\text { Mean } \\
\text { NDVI sum } \\
\text { (Jun-Aug) }\end{array}$ & $\begin{array}{r}\text { Mean NDVI } \\
\text { green-up (1st } \\
\text { derivative) }\end{array}$ & $\begin{array}{r}\text { Mean } \\
\text { NDVI } \\
\max \end{array}$ & $\begin{array}{r}\text { Mean } \\
\text { NDVI sum } \\
\text { (Jun-Aug) }\end{array}$ & $\begin{array}{r}\text { Mean NDVI } \\
\text { green-up (1st } \\
\text { derivative) }\end{array}$ \\
\hline All sites ( $n: 35)$ & -0.26 & -0.28 & $0.51^{b}$ & $-0.35^{\mathrm{a}}$ & $-0.36^{\mathrm{a}}$ & 0.32 & -0.30 & -0.30 & $0.47^{\mathrm{b}}$ \\
\hline Beech & 0.48 & 0.11 & $0.63^{\mathrm{a}}$ & 0.11 & -0.23 & 0.53 & 0.27 & 0.35 & $0.71^{\mathrm{a}}$ \\
\hline Oak & 0.17 & 0.07 & 0.55 & 0.21 & 0.07 & 0.19 & 0.09 & 0.02 & 0.37 \\
\hline Chestnut & -0.46 & -0.33 & 0.48 & -0.40 & -0.37 & 0.20 & -0.33 & 0.20 & 0.38 \\
\hline Grassland & -0.46 & -0.24 & 0.36 & -0.61 & -0.42 & 0.21 & -0.49 & -0.60 & 0.26 \\
\hline
\end{tabular}

${ }^{\mathrm{a}} \alpha<0.05^{\mathrm{b}} \alpha<0.01$ (two-tailed test). Correlation ( $r$ Pearson) performed between andosolization process $\left(\mathrm{Al}_{\mathrm{O}}+0.5 \mathrm{Fe}_{\mathrm{O}} \%\right)$ and NDVI metrics for each of the observed land cover classes (CORINE Land Cover classes, by APAT, 2000) after site validation. The chemical analyses are integrated over soil depth (solum).

suggesting that the water storage of these soils may play a key controlling role.

Our findings are also important to better acknowledge the occurrence and the importance of andic soils in $\mathrm{C}$ sequestration/storage estimates. All our soils had a high organic $\mathrm{C}$ content (mean 3.8\%), regardless of whether they were Andosols or Cambisols or Phaeozems.

Indeed, deep andic soils have much higher (Batjes, 1996; Matus et al., 2014) mean organic C content of (i) deep Regosols (3.1\%), (ii) Cambisols (5.0\%), and (iii) still higher than Humic and Leptic Podzols (respectively 10.3 and $12.8 \%$ ) which are considered as the main soil types as observed in previous soil inventories (Mancini, 1966; EuDASM, 2007) of the investigated landscapes.

\section{Conclusive remarks and future perspectives}

Our study shows a close relationship between the andosolization process and NDVI metrics and especially with metrics describing the acceleration of photosynthesis (green-up). This finding demonstrates that there is still much to be understood about the ecological importance of soils in mountain ecosystems, at least for the Italian territory.

Moreover, acknowledgment of the importance of these soils may also have consequences in terms of both soil protection in mountain environments (andic soils are known to be among the most vulnerable soils in the world in terms of soil erosion) and for better understanding of the impact of climate change. In this respect, this study suggests that the unique water retention features of the andic soils play an important ecological role when comparing contrasting climatic years.

The above results are perhaps even more pronounced considering that the current study employed a rather simplified NDVI approach including data at coarse resolution (MODIS) and no algorithm to mitigate the well-known saturation effect of NDVI (Buschmann and Nagel, 1993). Thus it is likely that in future, better focused studies may demonstrate even better and closer relationships between andic soils and green biomass indicators.

Generally, our results indicate the large potential in using remote sensed vegetation index metrics to ameliorate soil spatial inventories. A question still arises as to whether the general absence of strong significant correlation between $\mathrm{Al}_{\mathrm{o}}+0.5 \mathrm{Fe}_{\mathrm{o}}$ index with both "NDVI max" and "integrated NDVI sum" may be caused by the quoted NDVI saturation effect.

Regarding our results, we want to also emphasize that the importance of andosolization process in affecting ecosystem function is undoubtedly poorly expressed by soil classification: in fact strict classification rules dealing with how/where to expect "andic properties" (IUSS Working Group WRB, 2015: starting within $25 \mathrm{~cm}$ from the soil surface; SSS, 2014: within $60 \mathrm{~cm}$ ) can lead to non-Andosols with very high $\mathrm{Al}_{\mathrm{o}}+0.5 \mathrm{Fe}_{\mathrm{o}}$ index. However, the $\mathrm{Al}_{\mathrm{o}}+0.5 \mathrm{Fe}_{\mathrm{o}}$ index, rather 
than soil class criterion, seems to better explain variability in NDVI metrics and plant ecosystem dynamics, and this finding must be of major interest for ameliorating soil classification.

Although the importance of this key mineral soil in Italian mountain ecosystems is demonstrated to produce in turn large organic $\mathrm{C}$ storage and long $\mathrm{C}$ residence time, proper implementation of these new data in terms of $\mathrm{C}$ balance calculation, reducing uncertainties in carbon sequestration estimates and carbon sink national ecosystems inventory, is indeed a major issue to be addressed.

Moreover, the given wide recognition of andic soils has important consequences both in terms of $\mathrm{C}$ sequestration potentialities and $\mathrm{C}$ loss risks associated with this finding. Suitable land management techniques are then required to match the exclusive properties and problems connected to the presence of these soils.

Considering the many recent finds of andic soils worldwide, it is of great importance to ascertain whether a wider occurrence of this hidden resource applies also to mountain environments in other parts of the world.

Finally, we must emphasize that this study - focused on only 35 points over the Italian landscape - is a methodological basis for producing statements that could be valid at the national scale where, accordingly, much more data are indeed required.

Data availability. Data used in this paper are reported in the Supplement. Moreover in this paper we have used soil data of some specific pedon; these data have been obtained by selected publication already quoted in this paper.

\section{The Supplement related to this article is available online at https://doi.org/10.5194/se-9-63-2018-supplement.}

Competing interests. The authors declare that they have no conflict of interest.

Acknowledgements. We would like to thank Andrea Vacca, Giuseppe Maugeri and Antonio Mingo for helping us with sampling at some of the sites; Nadia Orefice and Roberto De Mascellis for performing the hydrological analysis; and Luciana Minieri for producing some of the chemical analysis.

Edited by: Marc Oliva

Reviewed by: two anonymous referees

\section{References}

Amundson, R.: The carbon budget in soils, Annu. Rev. Earth Pl. Sc., 29, 535-562, 2001.

Arnalds, O. and Stahr, K.: Volcanic soil resources: occurrence, development and properties, Catena (special issue) 56, 56, 1-2, 2004.

Arnalds, O., Thorarinsdottir, E. F., Metusalemsson, S., Jonsson, A., Gretarsson, E., and Arnason, A.: Soil erosion in Iceland, Soil Conservation Service and Agricultural Research Institute, Reykjavik, Iceland, 2001.

Bartoli, F. and Burtin, G.: Organo-mineral clay and physical properties in COST 622 European volcanic soils, in: Soils of Volcanic Regions in Europe, edited by: Arnalds, O. et al., Springer Verlag, Berlin Heidelberg, 469-491, 2007.

Bartoli, F., Burtin, G., and Herbillon, A.: Disaggregation and clay dispersion of Oxisols: Na-resin, a recommended methodology, Geoderma, 49, 301-307, 1991.

Basile, A., Mele, G., and Terribile, F.: Soil hydraulic behaviour of a selected benchmark soil involved in the landslide of Sarno 1998, Geoderma, 117, 331-346, 2003.

Basile, A., Coppola, A., De Mascellis, R., Mele, G., and Terribile, F.: A comparative analysis of the pore system in COST 622 volcanic soils by means of soil hydrology and image analysis, in: Soils of Volcanic Regions in Europe, edited by: Arnalds, O., Bartoli, F., Buurman, P., Oskarsson, H., Stoops, G., and GarciaRodeja, E., Springer Verlag, Berlin Heidelberg, 493-514, 2007.

Basile-Doelsch, I., Amundson, R., Stone, W. E. E., Masiello, C. A., Bottero, J. Y., Colin, F., Masin, F., Borschneck, D., and Meunier, J. D.: Mineralogical control of organic carbon dynamics in a volcanic ash soil on la Réunion, Eur. J. Soil Sci., 56, 689-703, 2005.

Batjes, N. H.: Total carbon and nitrogen in the soils of the world, Eur. J. Soil Sci., 47, 151-163, 1996.

Baumler, R., Caspari, T., Totsche, K. U., Dorji, T., Norbu, C., and Baillie, I. C.: Andic properties in soils developed from nonvolcanic materials in Central Bhutan, J. Plant Nutr. Soil Sc., 168, 703-713, 2005.

Blakemore, L. C., Searle, P. L., and Daly, B. K.: Methods for Chemical Analysis of Soils, New Zealand, Soil Bureau, Scientific Report 80, 1987.

Bolton, D. K. and Friedl, M. A.: Forecasting crop yield using remotely sensed vegetation indices and crop phenology metrics, Agr. Forest Meteorol., 173, 74-84, 2013.

Buschmann, C. and Nagel, E.: In vivo spectroscopy and internal optics of leaves as basis for remote sensing of vegetation, Int. J. Remote Sensing, 14, 711-722, 1993.

Chen, Y., Xu, X., and Zhang, D.: Correlation of vegetation distribution and terrain factors in northwestern of Sichuan Longmen mountain [J], Chinese J. Ecol., 25, 1052-1055, 2006.

Churchman, G. J., Bartoli, F., Burtin, G., Rouiller, J., and Weismann, D.: Comparison of methods using sodium for the size fractionation of soil, 11th Int Clay Conf Proc, 15-21 June 1997, Ottawa (Canada), 331-338, 1999.

Ciarkowska, K. and Miechówka, A.: The role of bilberry and Alpine lady-fern in soil formation within the Carpathian subalpine spruce forest stands, Geoderma, 305, 162-172, 2017.

Costantini, E. A. C., Urbano, F., and L'Abate, G.: Soil Regions of Italy, available at: www.soilmaps.it (last access: 12 January 2018), 2004. 
Costantini, E. A. C., Fantappie' M., and L'Abate, G.: Climate and pedoclimate of Italy, in: The Soils of Italy, World Soils Book Series, Springer Science, Business Media, Dordrecht, 2013.

Dane, J. H. and Hopmans, J. W.: Water retention and storage, in: Methods of Soil Analysis: Part 4 - Physical Methods, edited by: Dane, J. K., Topp, G. C., SSSA Book Ser. 5. SSSA, Madison, WI, pp. 671-720, 2002.

Dixon, R. K., Brown, S., Houghton, R. A., Solomon, A. M., Trexler, M. C., and Wisniewski, J.: Carbon pools and flux of global forest ecosystem, Science, 263, 185-190, 1994

Dümig, A., Schad, P., Kohok, M., Beyerlein, P., Schwimmer, W., and Kögel-Knabner, I.: A mosaic of nonallophanic Andosols, Umbrisols and Cambisols on rhyodacite in the southern Brazilian highlands, Geoderma, 145, 158-173, 2008.

EEA (European Environmental Agency): CLC2012Addendum to CLC2006 Technical Guidelines, available at: https: //land.copernicus.eu/user-corner/technical-library/Addendum_ finaldraft_v2_August_2014.pdf, last access: 12 January 2018.

Estevez, M. A., Cid, and McNunez, R. P.: Poorly-crystalline components in aggregates from soils under different land use and parent material, Catena, 144, 141-150, 2016.

EuDASM: European Digital Archive on Soil Maps of the World, available at: http://www.isric.org/projects/ eudasm-european-digital-archive-soil-maps (last access: 12 January 2018), February 2007.

FAO (Food and Agriculture Organization): Guidelines for Soil Profile Description (Revised), 4th Edn., Rome, 2006.

Fensholt, R. and Proud, S. R.: Evaluation of Earth Observation based global long term vegetation trends - comparing GIMMS and MODIS global NDVI time series, Remote Sensing Environ., 119, 131-147, 2012.

Frezzotti, M. and Narcisi, B.: Late quaternary tephra-derived paleosols in central Italy's carbonate Apennines range: stratigraphical and paleoclimatological implications, Quaternary Int., 34-36, 147-153, 1996.

Furuhata, A. and Hayashi, S.: Relation between soil structure and soil pore composition: case of volcanogenous soils in Tokachi district, Res. Bull. Hokkaido Natl. Agric. Exp. Stn., 126, 53-58, 1980.

Graham, R. C. and O'Geen, A. T.: Soil mineralogy trends in California landscapes, Geoderma, 154, 418-437, 2010.

Iamarino, M.: Andosuoli e suoli con proprietà andiche in aree non vulcaniche: un approccio a scala nazionale, $\mathrm{PhD}$ Thesis (Gestione e Valorizzazione delle risorse agro-forestali; XVII ciclo), Università degli Studi di Napoli Federico II, Napoli, Italy, 2005.

Iamarino, M. and Terribile, F.: The importance of andic soils in mountain ecosystems in Italy: a pedological investigation, Eur. J. Soil Sci., 59, 1284-1292, 2008.

IPCC: Guidelines for National Greenhouse Gas Inventories Volume 4 Agriculture, Forestry and Other Land Use, available at: http:// www.ipcc-nggip.iges.or.jp/public/2006gl/vol4.html (last access: 12 January 2018), 2006.

IUSS Working Group WRB: World Reference Base for Soil Resources 2014, update 2015 International soil classification system for naming soils and creating legends for soil maps, World Soil Resources Reports No. 106, FAO, Rome, 2015.

Iwata, S.: Soil moisture in volcanic ash soils. Soil physical conditions and plant growth, Japan, 18, 18-26, 1968.
Kutilek, M. and Nielsen, D. R.: Soil Hydrology, Catena Verlag, Geoscience Publ., Amsterdam, 370 pp., 1994.

Leamy, M. L.: Andisols of the world, in: Congreso Internacional de Suelos Volcánicos. Comunicaciones Secretariado de Publicaciones, La Universidad de La Laguna (Ed.), La Laguna, Spain, Serie Informes, 13, 368-387, 1984.

Lulli, L.: Volcanic soils in Italy, in: Soils of Volcanic Regions in Europe, edited by: Arnalds, O., Bartoli, F., Buurman, P., Oskarsson, H., Stoops, G., and Garcia-Rodeja, E., Springer Verlag, Berlin Heidelberg, 51-67, 2007.

Luo, Y., Ahlstrom, A., Allison, S. D., Batjes, N. H., Brovkin, V., Carvalhais, N., Chappell, A., Ciais, P., Davidson, E. A., Finzi, A.,Georgiou, K., Guenet, B., Hararuk, O., Harden, J. W., He, Y., Hopkins, F., Jiang, J., McGuire, A. D., Parton, W., Peng, C., Randerson, J. T., Salazar, A., Sierra, C. A., Smith, M. J., Tian, H., Todd-Brown, K. E. O., Torn, M., van Groenigen, K. J., Wang, Y. P., West, T. O., Wei, Y., Wieder, W. R., Xia, J., Xu, X., Xu, X., and Zhou, T.: Towards more realistic projections of soilcarbon dynamics by earth system models, Global Biogeochem. Cy., 30, 40-56, 2015.

Mancini, F.: Breve commento alla carta dei suoli d'Italia in scala 1:1.000.000, Ed. Coppini, Firenze, 80 pp., 1966.

Matus, F., Rumpel, C., Neculman, R., Panichini, M., and Mora, M. L.: Soil carbon storage and stabilization in andic soils: a review, Catena, 120, 102-110, 2014.

McDaniel, P. A. and Hipple, K. W.: Mineralogy of loess and volcanic ash eolian mantles in Pacific Northwest (USA) landscapes, Geoderma, 154, 438-446, 2010.

McDaniel, P. A., Wilson, M. A., Burt, R., Lammers, D., Thorson, T. D., Mcgrath, C. L., and Peterson, N.: Andic soils of the inland Pacific Northwest, USA: properties and ecological significance, Soil Sci., 170, 300-311, 2005.

McKee, T. B., Doesken, N. J., and Kleist, J.: The Relationship of Drought Frequency and Duration to Time Scales, Proceedings of the 8th Conference on Applied Climatology, 17-22 January 1993, Anaheim, CA. Boston, MA, American Meteorological Society, 1993.

Mileti, F. A., Langella, G., Prins, M. A., Vingiani, S., and Terribile, F.: The hidden nature of parent material of Italian mountain ecosystems, Geoderma, 207-208, 291-309, 2013.

Mileti, F. A., Vingiani, S., Manna, P., Langella, G., and Terribile, F.: An integrated approach to studying the genesis of andic soils in Italian nonvolcanic mountain ecosystems, Catena, 159, 35-50, 2017.

Mizota, C. and van Reeuwijk, L. P.: Clay mineralogy and chemistry of soils formed in volcanic material in diverse climatic regions, Soil Monograph 2, Wageningen: ISRIC, 186 pp., 1993.

Nanzyo, M.: Unique properties of volcanic ash soils, Global Environ. Res., 6, 83-97, 2002.

Nanzyo, M., Shoji, S., and Dahlgren, R.: Physical characteristics of volcanic ash soils, in: Volcanic Ash Soils. Genesis, Properties and Utilization, edited by: Shoji, S., Nanzyo, M., and Dahlgren, R., Elsevier, Amsterdam, London, New York, Tokyo, 189-207, 1993.

Nierop, K. G. J., van Bergen, P. F., Buurman, P., and van Lagen, $\mathrm{B}$.: $\mathrm{NaOH}$ and $\mathrm{Na}^{4} \mathrm{P}^{2} \mathrm{O}^{7}$ extractable organic matter in two allophanic volcanic ash soils of the Azores Islands - a pyrolysis GC/MS study, Geoderma, 127, 36-51, 2005. 
Parton, W., J., Schimel, D. S., Cole, C. V., and Ojima, D. S.: Analysis of factors controlling soil organic matter levels in Great Plains grassland, Soil Sci. Soc. Am. J., 51, 1173-1179, 1987.

Post, W. M.: Organic carbon in soils and the global carbon cycle, in: The Global Carbon Cycle, edited by: Heinmann, M., Springer, Berlin, 277-302, 1983.

Raab, G., Halperna, D., Scarciglia, F., Raimondi, S., Nortond, K., Pettkee, T., Hermanne, J., de Castro Portesa, R., and Aguilar Sanchez, A. M.: Linking tephrochronology and soil characteristics in the Sila and Nebrodi mountains, Italy, Catena, 158, 266285, 2017.

Rasmussen, C., Dahlgren, R. A., and Southard, R. J.: Basalt weathering and pedogenesis across an environmental gradient in the southern Cascade Range, California, USA, Geoderma, 154, 473485, 2010.

Reed, B. C., Brown, J. F., VanderZee, D., Loveland, T. R., Merchant, J. W., and Ohlen, D. O.: Measuring phenological variability from satellite imagery, J. Veg. Sci., 5, 703-714, 1994.

Rouse, J. W., Haas, R. H., Schell, J. A., Deering, D. W., and Harlan, J. C.: Monitoring the Vernal Advancement of Retrogradation of Natural Vegetation, NASA/GSFC type II, Progress Report RSC 1978-1, Greenbelt, MD, 371 pp., 1973.

Saigusa, M., Shoji, S., and Nakaminami, H.: Measurement of water retention at 15 bar tension by pressure membrane method and available moisture of Andosols, Jap. J. Soil Sci. Plant Nutr., 58, 374-377, 1987 (in Japanese).

Scarciglia, F., De Rosa, R., Vecchio, G., Apollaro, C., Robustelli, G., and Terrasi, F.: Volcanic soil formation in Calabria (southern Italy): the Cecita Lake geosol in the late Quaternary geomorphological evolution of the Sila uplands, J. Volcanol. Geoth. Res., 177, 101-117, 2008.

Shoji, S., Nanzyo, M., and Dahlgren, R.: Volcanic Ash Soils: Genesis, Properties and Utilization, Development in Soil Science, Elsevier, Amsterdam, vol. 21, 288 p., 1993.

Soil Survey Staff: Keys to Soil Taxonomy, 12th Edn., USDANatural Resources Conservation Service, Washington, DC, 2014.

Schwertmann, U.: Differenzierung der Eisenoxide des Bodens durch photochemische Extraktion mit saurer AmmoniumoxalatLösung, Z. Pflanzenernähr., 105, 194-202, 1964.

Teissier du Cros, E., Le Tacon, F., Nepveu, G. Pard, J., Perrin, R., and Timbal, J.: Le Hetre, INRA Department des Reserches Forestieres, Paris, France, 1981.

Terribile, F., Basile, A., De Mascellis, R., Iamarino, M., Magliulo, P., Pepe, S., and Vingiani, S.: Landslide processes and Andosols: the case study of the Campania region, Italy, in: Soils of Volcanic Regions in Europe, edited by: Arnalds, O., Bartoli, F., Buurman, P., Oskarsson, H., Stoops, G., and Garcia-Rodeja, E., Springer Verlag, Berlin Heidelberg, 545-563, 2007.
Torn, S. M., Trumbore, S. E., Chadwick, O. A., Vitousek, P. M., and Hendricks, D. M.: Mineral control of soil organic carbon storage and turnover, Nature, 389, 170-173, 1997.

Tucker, C. J. and Sellers, P. J.: Satellite remote sensing of primary production, Int. J. Remote Sensing, 7, 1395-1416, 1986.

Ugolini, F. C., Dahlgren, R. A., Shoji, S., and Ito, T.: An example of andosolization and podsolization as revealed by soil solution studies, southern Hakkoda, northeastern Japan, Soil Sci., 145, 111-125, 1988.

USDA-NRCS: Soil Survey laboratory methods manual, Soil Survey Investigation Report 42, Version 4, 700 pp., 2004.

van Genuchten, M. T.: A closed-form equation for predicting the hydraulic conductivity of unsaturated soils, Soil Sci. Soc. Am. J., 44, 892-898, 1980.

Vingiani, S., Scarciglia, F., Mileti, F. A., Donato, P., and Terribile, F.: Occurrence and origin of soils with andic properties in Calabria (southern Italy), Geoderma, 232-234, 500-516, 2014.

Vingiani, S., Mele, G., De Mascellis, R., Terribile, F., and Basile, A.: Volcanic soils and landslides: a case study of the island of Ischia (southern Italy) and its relationship with other Campania events, Solid Earth, 6, 783-797, https://doi.org/10.5194/se6-783-2015, 2015.

Walkley, A.: A critical examination of a rapid method for determining organic carbon in soils - effect of variations in digestion conditions and of inorganic soil constituents, Soil Sci., 63, 251-265, 1947.

Walsh, S. J., Crawford, T. W., Walsh, S. J., Crawford, T. W., Welsh, W. F., and Crews-Meyer, K. A.: A multi-scale analysis of LULC and NDVI variation in Nang Rong district, northeast Thailand[J], Agr. Ecosyst. Environ., 85, 47-64, 2001.

Wang, J., Rich, P. M., Price, K. P., and Kettle, W. D.: Relations between NDVI and tree productivity in the central great plains, Int. J. Remote Sensing, 25, 3127-3138, 2004.

Yosef, H. and Tamhane, A. C.: Multiple Comparison Procedures, John Wiley and Sons, Inc., 450 pp., https://doi.org/10.1002/9780470316672, 2008.

Zhan, Z.-Z., Liu, H.-B., Li, H.-M., Wu, W., and Zhong, B.: The relationship between NDVI and terrain factors - a case study of Chongqing, Proc. Environ. Sci., 12, 765-771, 2012.

Zhang, X., Friedl, M. A., Schaaf, C. B., Strahler, A. H., Hodges, J. C. F., Gao, F., Reed, B. C., and Huete, A.: Monitoring vegetation phenology using MODIS, Remote Sens. Environ., 84, 471-475, 2003. 